\begin{tabular}{|l|l|l||}
\hline \multicolumn{2}{|c|}{ PublisherInfo } \\
\hline \hline PublisherName & $:$ & BioMed Central \\
\hline \hline PublisherLocation & $:$ & London \\
\hline \hline PublisherImprintName & $:$ & BioMed Central \\
\hline \hline
\end{tabular}

\title{
Plants cope better without telomerase
}

\begin{tabular}{||l|l|l||}
\hline \multicolumn{2}{|c|}{ ArticleInfo } \\
\hline \hline ArticleID & $:$ & 3998 \\
\hline \hline ArticleDOI & $:$ & $10.1186 /$ gb-spotlight-20010302-01 \\
\hline \hline ArticleCitationID & $:$ & spotlight-20010302-01 \\
\hline \hline ArticleSequenceNumber & $:$ & 69 \\
\hline \hline ArticleCategory & $:$ & Research news \\
\hline \hline ArticleFirstPage & $:$ & 1 \\
\hline \hline ArticleLastPage & $:$ & 2 \\
\hline \hline & & RegistrationDate : 2001-03-02 \\
ArticleHistory & $:$ & OnlineDate $\quad$ 2001-03-02 \\
\hline \hline ArticleCopyright & $:$ & BioMed Central Ltd2001 \\
\hline \hline ArticleGrants & $:$ & \\
\hline \hline ArticleContext & $:$ & 130592211 \\
\hline \hline
\end{tabular}




\section{Jonathan B Weitzman}

Email: jonathanweitzman@hotmail.com

Mice lacking telomerase exhibit reduced fertility and severe developmental defects after a few generations. In the March 2 Science, Riha et al. report the effects of telomere shortening in Arabidopsis thaliana (Science 2001, 291:1797-1800). Homozygous telomerase-deficient plants displayed progressive telomere shortening (250-500 base pairs per generation). Defects in vegetative organs and reproductive systems did not appear before the sixth generation (reduced leaf size and symmetry), however. These defects coincided with the appearance of anaphase bridges - failure of chromosomes to separate at mitosis - and the chromosome fusions observed in late-generation plants correlated with the severity of developmental defects. Plant cells continued to cycle despite cytogenetic aberrations, however, until they reached 'genomic catastrophe'. Mutants eventually arrested at a terminal vegetative state with widespread disorganization and dedifferentiated calluses. Riha et al. could not detect evidence for apoptosis or senescence, which are seen upon telomere loss in metazoa.

\section{References}

1. Telomere shortening and tumor formation by mouse cells lacking telomerase RNA.

2. Science, [http://www.sciencemag.org] 